\title{
Telenomus remus (Hymenoptera: Platygastridae) parasitism on Spodoptera frugiperda (Lepidoptera: Noctuidae) eggs: different parasitoid and host egg ages
}

\section{Parasitismo de Telenomus remus (Hymenoptera: Platygastridae) em ovos de Spodoptera frugiperda (Lepidoptera: Noctuidae): diferentes idades do parasitoide e do ovo hospedeiro}

\author{
Ana Paula de Queiroz ${ }^{1 *}$; Bruna Magda Favetti²; Pamela Gislaine Gellert Luski³; \\ Jaciara Gonçalves ${ }^{4}$; Pedro Manuel Oliveira Janeiro Neves ${ }^{5}$; \\ Adeney de Freitas Bueno ${ }^{6}$
}

\begin{abstract}
Release of egg parasitoids for biological control of pests is a promising technique in integrated pest management (IPM). However, there is a lack of information on the performance of parasitoid females of different ages, and specifically on the behavior of the parasitoid Telenomus remus towards pest eggs at different stages of embryonic development. Thus, the relationships between host age, parasitoid age, and parasitism by T. remus on Spodoptera frugiperda eggs were evaluated. Three separate bioassays were performed, each in a completely randomized design. In the first bioassay, $T$. remus females grouped by age in days (ranging from 1 to 10 days old) were offered $100 \pm 20$ eggs of $S$. frugiperda for 24 hours. In the second bioassay, $100 \pm 20$ eggs of $S$. frugiperda (24, 48 or 72 hours old) were offered to females of $T$. remus for 24 hours. In the third bioassay, 24, 48- and 72-hour-old host eggs of $S$. frugiperda were offered to T. remus females in a choice test. The variables evaluated were: number of parasitized eggs, parasitoid emergence (\%), and sex ratio of progeny in bioassays 1 and 2, and the number of eggs parasitized in bioassay 3 . The age of $T$. remus females did not affect the number of $S$. frugiperda eggs parasitized or emergence of the progeny. However, the sex ratio was more male-biased in the progeny of 1- and 2-day-old females compared to older wasps. In bioassay 2, the highest parasitism was observed in 24- and 48-hour-old eggs. Percentage emergence and sex ratios were not influenced by the ages of the eggs tested. Telenomus remus preferred to parasitize 24-hour-old eggs in bioassays 3. Overall, the age of $T$. remus females tested did not affect the parasitism of S. frugiperda eggs, but the number of eggs parasitized decreased with increasing host age.
\end{abstract}

Key words: Fall armyworm. Biological control. Egg parasitoid. Embryonic development.

1 Bióloga, Discente, Curso de Doutorado do Programa de Pós-Graduação em Entomologia, Universidade Federal do Paraná, UFPR, Departamento de Zoologia, Curitiba, PR, Brasil. E-mail: anna.paullaqueiroz@hotmail.com

2 Bióloga, Drª Instituto Agronômico do Paraná, IAPAR, Londrina, PR, Brasil. E-mail: favettibruna@yahoo.com.br

3 Eng ${ }^{\mathrm{a}}$ Agra , Discente, Curso de Mestrado do Programa de Pós-Graduação em Agronomia, Universidade Estadual de Londrina, UEL, Departamento de Agronomia, Londrina PR, Brasil. E-mail: pamela.luski@hotmail.com

4 Eng $^{\text {a }}$ Agr $^{\text {a }}$, Discente, Curso de Doutorado do Programa de Pós-Graduação em Entomologia, UFPR, Departamento de Zoologia, Curitiba, PR, Brasil. E-mail: jaciarag@gmail.com

5 Eng $^{\mathrm{o}}$ Agr $^{\mathrm{o}}$, Prof. Dr., Departamento de Agronomia, CCA, UEL, Londrina, PR, Brasil. E-mail: pedroneves@uel.br

${ }^{6}$ Eng $^{\circ}$ Agr $^{\circ}$, Dr. Pesquisador, Empresa Brasileira de Pesquisa Agropecuária, EMBRAPA Soja, Londrina, PR, Brasil. E-mail: adeney.bueno@embrapa.br

* Author for correspondence 


\title{
Resumo
}

\begin{abstract}
A liberação de parasitoides de ovos para o controle biológico de pragas é uma técnica promissora no manejo integrado de pragas (IPM). Entretanto, há uma carência de informações sobre o desempenho de fêmeas do parasitoide em suas diferentes idades assim como do comportamento e parasitismo de Telenomus remus em ovos da praga em diferentes estádios de desenvolvimento embrionário. Avaliouse a relação entre idade do hospedeiro, idade do parasitoide e parasitismo de T. remus em ovos de Spodoptera frugiperda. Três bioensaios separados foram realizados, cada um em um delineamento inteiramente casualizado. No primeiro bioensaio, as fêmeas de T. remus agrupadas por idade em dias (variando de 1 a 10 dias de idade) foram oferecidas $100 \pm 20$ ovos de $S$. frugiperda por 24 horas. No segundo bioensaio, $100 \pm 20$ ovos de $S$. frugiperda (24, 48 ou 72 horas de idade) foram oferecidos às fêmeas de T. remus por 24 horas. No terceiro bioensaio, ovos hospedeiros de 24,48 e 72 horas de idade de $S$. frugiperda foram oferecidos para fêmeas de T. remus em teste de escolha. As variáveis avaliadas foram: número de ovos parasitados, emergência do parasitoide (\%) e razão sexual da progênie nos bioensaios 1 e 2 e o número de ovos parasitados no bioensaio 3. A idade das fêmeas de T. remus não afetou o número de ovos de $S$. frugiperda parasitados ou a emergência da progênie. No entanto, a razão sexual foi mais tendenciosa no sexo masculino na progênie de fêmeas de 1 e 2 dias de idade em comparação com as vespas mais velhas. In bioassay 2 , the highest parasitism was observed in 24- and 48-hour-old eggs. A porcentagem de emergência e a razão sexual não foram influenciadas pela idade dos ovos testados. Telenomus remus preferiu parasitar ovos de 24 horas no bioensaios 3 . No geral, a idade das fêmeas de $T$. remus testadas não afetou o parasitismo dos ovos de $S$. frugiperda, mas o número de ovos parasitados diminuiu com o aumento da idade do hospedeiro.
\end{abstract}

Palavras-chave: Lagarta-do-cartucho. Controle biológico. Parasitoide de ovos. Desenvolvimento embrionário.

\section{Introduction}

Spodopterafrugiperda(J.E. Smith)(Lepidoptera: Noctuidae) can be responsible for significant yield reductions in corn, and is considered the most important corn pest in Brazil and other countries worldwide (CRUZ, 2008; MENDES et al., 2011). This lepidopteran is polyphagous, feeding on approximately 180 plant species (CASMUZ et al., 2010), notably including corn, rice, and cotton (BUSATO et al., 2004; MARTINELLI et al., 2007). This characteristic, as well as its ability to adapt to different climates, results in $S$. frugiperda having a broad geographical distribution, and it can cause problems in all Brazilian agricultural areas at different periods of the year (POGUE, 2002).

Management of this pest relies mainly on spraying chemical insecticides, which is the most common tool used by farmers. However, inappropriate use of insecticides can lead to problems such as elimination of natural enemies (SILVA et al., 2016; GRANDE et al., 2018), selection of insecticide-resistant pest populations, environmental contamination, and increases in production costs, among others (FERNANDES et al., 2010). Therefore, the use of more sustainable pest control tactics to keep pest population below the economic damage level without the exclusive use of chemicals (VAN LENTEREN et al., 2017) is fundamental to reducing the negative effects agriculture might have on the environment.

Biological control through release of egg parasitoids is a promising tool for integrated pest management (IPM) (VAN LENTEREN et al., 2017). In this context, Telenomus remus (Nixon) (Hymenoptera: Platygastridae) deserves special attention for control of pests of the genus Spodoptera (POMARI et al., 2013). These wasps can be used in augmentative releases with great potential for success due to their high reproductive capacity and efficiency against the target pest (CAVE, 2000). However, one of the factors that can reduce the efficiency of this parasitoid in the field is the lack 
of synchronization between occurrence of the most susceptible age of the pest egg and the age at which adult parasitoids released into the environment have their highest activity of parasitism (CINGOLANI et al., 2014). There is a lack of information on the performance of parasitoid females of different ages, and on the behavior of $T$. remus towards pest eggs at different embryonic development stages. The published papers in this field (VENTURA et al., 2001; POLANCZYK et al., 2007; PIZZOL et al., 2012) are restricted to the genus Trichogramma, and have shown that the age of female parasitoids affects their ability to control the target pest. Understanding this information is essential to provide appropriate recommendations for use of parasitoids in augmentative biological control $(\mathrm{ABC})$ programs, but is still absent in the literature for $T$. remus.

According to Zuim et al. (2017), the performance of a parasitoid in an $\mathrm{ABC}$ program partially depends on its host selection behavior. The advance in embryonic development can reduce egg acceptance by parasitoids, consequently reducing parasitism (LOPES; PARRA, 1991; OLIVEIRA et al., 2003; ROCHA et al., 2006; ZUIM et al., 2017). Therefore, studies evaluating responses of $T$. remus females of different ages to $S$. frugiperda eggs at different stages of embryonic development can provide essential information to optimize the use of this parasitoid in $\mathrm{ABC}$ programs. Thus, the objective of this study was to evaluate the influence of $T$. remus female age on parasitism of $S$. frugiperda eggs, and preferences of $T$. remus for $S$. frugiperda eggs of different ages.

\section{Material and Methods}

\section{Host and parasitoid rearing}

Eggs of $S$. frugiperda and adult $T$. remus females used in the experiments came from insect colonies kept at Embrapa Soja, Londrina, State of Paraná, Brazil. These species were reared under controlled laboratory conditions following Greene et al. (1976) (for $S$. frugiperda) and Bueno et al. (2008) (for $T$. remus) in acclimatized rooms at $25 \pm 2{ }^{\circ} \mathrm{C}, 70 \pm 10 \%$ humidity, and 14/10 h (L/D) photoperiod, as briefly described in the following.

Adults of $S$. frugiperda were kept in cages (45 $\mathrm{cm}$ length $\times 33 \mathrm{~cm}$ width $\times 35 \mathrm{~cm}$ height) lined with white sulfite paper on their sides as a substrate for oviposition. For adult feeding, a solution containing honey $(10 \%)$ and distilled water was offered. Egg masses were removed daily and were either used for experiments, or used for maintenance of the colony by keeping the $S$. frugiperda larvae on artificial diet (GREENE et al., 1976) in plastic cups (50 mL) until the pupal stage.

For $T$. remus rearing, $S$. frugiperda egg masses were glued to pieces of cardboard $(10 \mathrm{~cm} \times 12$ $\mathrm{cm})$ and introduced into plastic recipients $(2 \mathrm{~L})$ containing newly emerged $T$. remus adults $(\leq 24 \mathrm{~h}$ since emergence). Honey droplets were placed on the inner wall of the recipients to provide food for the adults. The cardboards were kept in the recipient for 24 hours to allow parasitism. They were then collected and stored in new plastic recipient $(2 \mathrm{~L})$ until the emergence of adults, which were then used for experiments or for colony maintenance.

\section{Bioassays}

Three independent experiments were conducted. In the first experiment, parasitism of $S$. frugiperda eggs by $T$. remus females of different ages was studied. In the second, the susceptibility of $S$. frugiperda eggs of different ages to parasitism by $T$. remus was evaluated. Finally, in the third, preference of $T$. remus for $S$. frugiperda eggs of different ages was studied. All tests were performed under controlled conditions within biochemical oxygen demand (BOD) climatic chambers (ELETROLab ${ }^{\circledR}$, EL 212 model, São Paulo, SP, Brazil) at a temperature of $25 \pm 2{ }^{\circ} \mathrm{C}$, relative humidity of $80 \pm$ $10 \%$, and photoperiod of $14 / 10 \mathrm{~h}(\mathrm{~L} / \mathrm{D})$. 
Parasitism of $S$. frugiperda eggs by T. remus females of different ages

The experiment was conducted in a completely randomized design with 10 treatments (adult females from 1 to 10 days old from the same laboratory generation) and 4 replicates $(\mathrm{N}=40)$. Each replicate consisted of five females individualized in plastic microtubes ( $12 \mathrm{~mm}$ diameter $\times 75 \mathrm{~mm}$ height) (four replicates $\times$ five females per replicate $=20$ females evaluated per treatment) following methodology proposed by Queiroz et al. (2017a). Rather than using a single female parasitoid per replicate, a group of females was used to increase the representativeness of the replicate to the species under study. Female parasitoids of insect eggs are small and fragile, and thus vulnerable to tiny injuries during experimental manipulation which could affect their behavior. Using a set of parasitoids for each replicate can partly mitigate this potential negative effect of experimental manipulation.

To obtain adult female parasitoids used in this bioassay, eggs of $S$. frugiperda parasitized by $T$. remus were stored in plastic recipients $(12 \mathrm{~cm}$ diameter $\times 25 \mathrm{~cm}$ height) and sealed with PVC film until emergence of adult parasitoids. After emergence, droplets (approximately $100 \mu \mathrm{l}$ each) of pure honey were placed on the walls of the tubes for adult feeding. After 24 hours, 200 females of $T$. remus were then transferred into plastic microtubes (12 mm diameter $\times 75 \mathrm{~mm}$ height) and sealed with plastic PVC film. A droplet of pure honey (approximately $100 \mu \mathrm{l}$ ) was also used for adult feeding. Then, eggs of $S$. frugiperda (100 \pm 20 eggs aged $\leq 24 \mathrm{~h}$ ) were glued onto pieces of white cardboards $(1 \mathrm{~cm} \times 6 \mathrm{~cm})$, labeled with their treatment, and one card was placed in each microtube containing female parasitoids. This procedure was performed for each 20 females (4 replicates of 5 female parasitoids) during 10 days. It offered the treatments of parasitoid females ranging from one to 10 days old. The cards were exposed to parasitism for 24 hours. After that, the females were removed, leaving only the cardboard in the microtubes, which were sealed with PVC plastic film and kept under the same conditions, until the emergence of adults ( $9 \pm 2$ days). The variables evaluated for each card were: number of parasitized eggs, parasitoid emergence (\%), and sex ratio of emerged parasitoids.

\section{Susceptibility of S. frugiperda eggs of different ages} to $T$. remus parasitism

The experiment was conducted in a completely randomized design with three treatments $(S$. frugiperda eggs at 24, 48, and 72 hours old) and 4 replicates $(\mathrm{N}=12)$. Each replicate consisted of five individualized females $(4$ replicates $\times 5$ females per replicate $=20$ females evaluated per treatment). The eggs were kept in BOD climatic chambers under the conditions previously described for 48 or 72 hours before setting up the experiment.

Females of $T$. remus ( $\leq 24$ since emergence) were transferred into microtubes $(12 \mathrm{~mm}$ diameter $\times 75 \mathrm{~mm}$ height) containing pure honey droplets (approximately $100 \mu \mathrm{l}$ each) for adult feeding. Afterwards, white pieces of cardboard $(1 \mathrm{~cm} \times 6$ $\mathrm{cm})$ containing $S$. frugiperda eggs $(100 \pm 20 \mathrm{eggs})$ of different ages $(24,48$, or 72 hours) were inserted into the microtubes, which each contained one $T$. remus female, and parasitism was allowed for 24 hours. After this period, females were removed and microtubes containing the cardboards were sealed with plastic PVC film and kept under the same conditions until adult emergence ( $9 \pm 2$ days). The parameters evaluated were: number of parasitized eggs, parasitoid emergence (\%), and sex ratio of emerged parasitoids.

\section{Preference of $T$. remus for $S$. frugiperda eggs of different ages}

The experiment was conducted in a completely randomized design with 3 treatments ( $S$. frugiperda eggs at 24, 48, and 72 hours old) and 15 replicates (one arena per replicate). This host preference 
test was conducted using arenas adapted from Thuller et al. (2007) as modified by Queiroz et al. (2017b). Arenas consisted of polyethylene bottles ( $2 \mathrm{~cm}$ diameter $\mathrm{x} 4 \mathrm{~cm}$ height) containing six plastic microtubes $(12 \mathrm{~mm}$ diamater $\times 75 \mathrm{~mm}$ height $)$ arranged equidistantly apart in the lower part of the bottle, and one microtube $(12 \mathrm{~mm}$ diameter $\times 75$ mm height) placed at the top of the arena (Figure 1).

Figure 1. Arenas adapted from Thuler et al. (2007) as modified by Queiroz et al. (2017b) used in the host preference test for the parasitoid Telenomus remus.

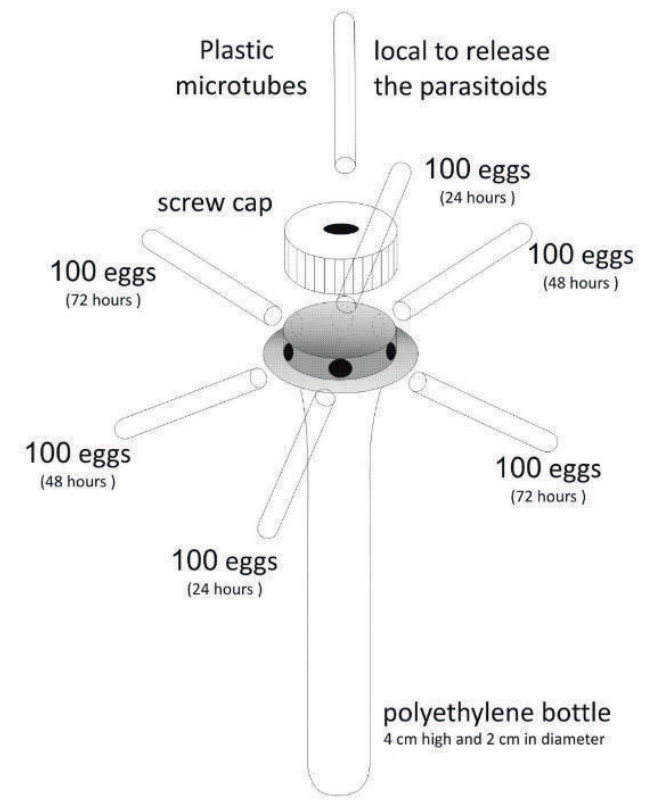

Eggs for each treatment $(100 \pm 20$ eggs of $S$. frugiperda 24,48 or 72 hours old) were glued on white cardboards $(1 \mathrm{~cm} \times 6 \mathrm{~cm})$. Then, two cardboards of each treatment were introduced into the microtubes, with cards of the same treatment placed on opposite sides (Figure 1). Six newly emerged T. remus females ( $\leq 24$ since emergence, with no previous parasitism experience) were released into the top each arena (hence, a rate of one female per $100 \pm 20$ eggs) and parasitism was allowed for 24 hours. After the 24hour period, cardboards were removed and kept in BOD climatic chambers until emergence of adults. The number of parasitized eggs in each treatment was evaluated, which allowed for calculation of the percentage parasitized in each treatment in relation to total parasitism observed in the arena (parasitism distribution \%).

\section{Statistical analysis}

Response variables from all three bioassays were evaluated for normality of residuals (SHAPIRO; WILK, 1965) and homogeneity of variance between treatments for ANOVA (BURR; FOSTER, 1972). For analysis of $S$. frugiperda egg parasitism by $T$. remus females of different ages, and for susceptibility of $S$. frugiperda eggs of different ages, percentage emergence was subjected to arcsine transformation before ANOVA. For analysis of T. remus preference for $S$. frugiperda eggs of different ages, the number of parasitized eggs was transformed by $\log (\mathrm{X}+1)$ before ANOVA. Then, the means were compared by Tukey test $(\alpha=0.05)$ using SAS statistical software (SAS INSTITUTE, 2009). 


\section{Results}

Parasitism of S. frugiperda eggs by T. remus females of different ages

The age of female $T$. remus wasps did not affect the number of parasitized S. frugiperda eggs, or the percentage emergence of adult parasitoids. Parasitoid sex ratios were affected by the age of wasps, as parasitism by 1- and 2-day-old T. remus females generated a lower proportion of females in the second generation ( 0.61 and 0.62 , respectively) when compared to progeny from 9-day-old females (0.88) (Table 1). However, the other treatments did not differ among themselves and all had a sex ratio higher than 0.60 (Table 1).

Table 1. The number of parasitized eggs, parasitoid emergence, and sex ratios of wasps emerging from Spodoptera frugiperda eggs parasitized by Telenomus remus females of different ages. The bioassay was performed under controlled conditions with a temperature of $25 \pm 2^{\circ} \mathrm{C}$, relative humidity of $80 \pm 10 \%$, and a photoperiod of $14 / 10 \mathrm{~h}$ $(\mathrm{L} / \mathrm{D})$.

\begin{tabular}{cccc}
\hline Female age (days) & Parasitized eggs $(\mathrm{n})$ & Emergence $(\%)^{1}$ & Sex ratio $^{2}$ \\
\hline 1 & $64.23 \pm 5.01^{\mathrm{ns}}$ & $98.25 \pm 0.69^{\mathrm{ns}}$ & $0.61 \pm 0.06 \mathrm{~b}$ \\
2 & $63.35 \pm 6.73$ & $97.68 \pm 0.49$ & $0.62 \pm 0.06 \mathrm{~b}$ \\
3 & $52.50 \pm 6.38$ & $96.07 \pm 1.18$ & $0.77 \pm 0.03 \mathrm{ab}$ \\
4 & $70.85 \pm 5.29$ & $97.33 \pm 0.69$ & $0.80 \pm 0.05 \mathrm{ab}$ \\
5 & $67.58 \pm 3.12$ & $98.22 \pm 0.68$ & $0.83 \pm 0.04 \mathrm{ab}$ \\
6 & $79.96 \pm 6.36$ & $99.45 \pm 0.21$ & $0.81 \pm 0.04 \mathrm{ab}$ \\
7 & $75.90 \pm 4.40$ & $97.91 \pm 0.60$ & $0.70 \pm 0.03 \mathrm{ab}$ \\
8 & $60.43 \pm 8.18$ & $96.50 \pm 2.30$ & $0.76 \pm 0.08 \mathrm{ab}$ \\
9 & $64.81 \pm 5.81$ & $97.91 \pm 0.72$ & $0.88 \pm 0.01 \mathrm{a}$ \\
10 & $56.05 \pm 9.48$ & $96.66 \pm 0.90$ & $0.75 \pm 0.07 \mathrm{ab}$ \\
$\mathrm{CV}(\%)$ & 19.27 & 3.9 & 13.16 \\
$\mathrm{~F}$ & 1.78 & 1.09 & 3.17 \\
$\mathrm{P}$ & 0.1132 & 0.4003 & 0.0083 \\
$\mathrm{df}$ & 39 & 38 & 39 \\
\hline
\end{tabular}

Means \pm standard error followed by the same letter in the column do not differ according to Tukey test $(\alpha=0.05)$ following ANOVA. 'Data were transformed by arcsine for analysis by ANOVA; untransformed means are presented. ${ }^{2}$ Sex ratio $=$ number of

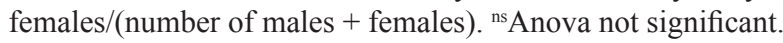

Susceptibility of S. frugiperda eggs of different ages to $T$. remus parasitism

Eggs of different ages differed in their susceptibility to parasitism by $S$. frugiperda. Eggs 24- and 48-hour-old were equally parasitized, but both were more parasitized than 72-hour-old eggs (Table 2). On the other hand, S. frugiperda egg age did not affect percentage $T$. remus emergence or its sex ratio (Table 2).
Preference of T. remus for $S$. frugiperda eggs of different ages

Spodoptera frugiperda egg age influenced parasitism distribution (\%) of $T$. remus (host preference). Significantly more 24-hour-old eggs were parasitized (mean $=116.81$ eggs) than 48 -hourold eggs (18.18), which in turn was higher than the number of 72-hour-old parasitized eggs (only 0.36 ) (Table 2). 
Table 2. The number of parasitized eggs, percentage emergence, and sex ratios of wasps emerging from Spodoptera frugiperda eggs of different parasitized by Telenomus remus in choice tests, and parasitism preference for different ages of eggs. The bioassay was performed under controlled conditions with a temperature of $25 \pm 2^{\circ} \mathrm{C}$, relative humidity of $80 \pm 10 \%$, and a photoperiod of $14 / 10 \mathrm{~h}(\mathrm{~L} / \mathrm{D})$.

\begin{tabular}{ccccc}
\hline \multirow{2}{*}{ Egg age (h) } & \multicolumn{3}{c}{ Biological characteristics } & Parasitism preference \\
\cline { 2 - 5 } & Parasitized eggs (n) & Emergence $(\%)^{1}$ & Sex ratio & $\begin{array}{c}\text { Number of parasitized eggs } \\
\text { (parasitism distribution \%) }\end{array}$ \\
\hline 24 & $57.95 \pm 2.83 \mathrm{a}$ & $98.48 \pm 0.79^{\text {ns }}$ & $0.69 \pm 0.06^{\text {ns }}$ & $116.81 \pm 12.70 \mathrm{a}(89.95 \%)$ \\
48 & $56.83 \pm 12.64 \mathrm{a}$ & $99.66 \pm 0.34$ & $0.74 \pm 0.09$ & $18.18 \pm 9.28 \mathrm{~b}(9.81 \%)$ \\
72 & $16.83 \pm 10.86 \mathrm{~b}$ & $95.66 \pm 4.34$ & $0.83 \pm 0.14$ & $0.36 \pm 0.28 \mathrm{c}(0.24 \%)$ \\
$\mathrm{CV}(\%)$ & 35.04 & 5.9 & 23.47 & 48.87 \\
$\mathrm{~F}$ & 6.89 & 0.55 & 0.54 & 49.93 \\
$\mathrm{P}$ & 0.0222 & 0.5968 & 0.6008 & $<0.0001$ \\
$\mathrm{df}_{\text {total }}$ & 9 & 10 & 10 & 32 \\
\hline
\end{tabular}

Means \pm standard error followed by the same letter in the column do not differ according to Tukey test $(\alpha=0.05)$. ${ }^{1}$ Data were transformed by arcsine for analysis by ANOVA; untransformed means are presented. ${ }^{2}$ Data were transformed by log $(\mathrm{X}+1)$ for

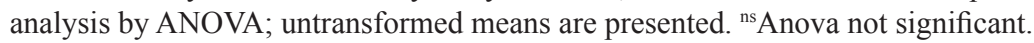

\section{Discussion}

Factors that potentially affect efficiency of egg parasitoids in $\mathrm{ABC}$ have been well documented. Among these factors, the most well-studied include temperature (OZDER; KARA, 2010; PIZZOL et al., 2010) and the host species used for rearing the parasitoids (OZDER; KARA, 2010). However, there are few studies to date on the potential effects of host egg age (PAK et al., 1986; MOREAU et al., 2009; MORENO et al., 2009) and the age of the parasitoids (GARCIA et al., 2001; PIZZOL et al., 2012) on parasitism. In addition, most of these studies focused on trichogrammatids and none of them studied T. remus. Thus, as far as we know, this study is the first to report relationships between parasitoid and host ages affecting parasitism by $T$. remus on $S$. frugiperda eggs. The understanding of these effects could contribute significantly to improvements in rearing and use of this parasitoid successfully for ABC programs. Timing the release parasitoids in the field to match the period when their hosts are more susceptible to parasitism is one of the main challenges for success in ABC (VAN LENTEREN et al., 2017). Therefore, studies that evaluate different biological aspects, including host dynamics, are important to determine the parasitism capacity and potential for success of the biological control agent under study (OLIVEIRA et al., 2016). Thus, knowledge of the biological aspects presented in this article, such as parasitism by females of different ages, and susceptibility of eggs at different stages of embryonic development to parasitism, is essential to evaluate the potential of $T$. remus in the field. In the field, various conditions such as host deprivation, eggs of different ages, and others could influence parasitism. In addition, storage tactics and parasitoid utilization in the laboratory can be improved with the knowledge obtained in this work, aiming for better functioning of laboratory production to meet input needs in the field.

Considering the relationship between the age of the parasitoid and level of parasitism by $T$. remus, there is great potential for this parasitoid to contribute to $\mathrm{ABC}$ strategies compared to trichogrammatids. Parasitism by $T$. remus was similar for females between 1 to 10 days old, whereas for Trichogramma spp., parasitism is generally concentrated in the first days of life (BUENO et al., 2012). This is usually because most species of the genus Trichogramma have the ability to store a complement of mature 
eggs in their ovaries or oviducts, and complete oogenesis before or shortly after the emergence of adults (i.e., they are pro-ovigenic parasitoids) (MILLS; KUHLMANN, 2000). Thus, adults emerge ready to oviposit. Under conditions of host deprivation, Trichogramma spp. females can eventually reabsorb their oocytes, reducing their parasitism and period of fertility (HOUGARDY et al., 2005). In contrast, some other species of egg parasitoids, such $T$. remus as observed in the present study, are able to retain eggs in the absence of hosts and thus maintain their rates of parasitism even after several days of host deprivation. This improves their chances to successfully parasitize hosts in the field, especially in areas of constant fluctuation population size of the target pest (CHABI-OLAYE et al., 2001; CARNEIRO et al., 2009). The ability of females to adjust egg production according to host availability can provide a reproductive advantage (FLEURY; BOULETREAU, 1993; HOUGARDY et al., 2005). For example, the ability to parasitize even after ten days of host deprivation is clearly an advantage for the use of $T$. remus in $\mathrm{ABC}$ programs. In field conditions, it is possible for females to not find eggs immediately, resulting in a need to forage for longer (BIEVER, 1972). Thus, considering our results, which showed that during the first ten days of parasitoid adult life there was no decrease in reproductive potential, $T$. remus will probably be capable of foraging longer in the search of hosts compared with trichogrammatids.

Greater flexibility in parasitism by $T$. remus, which even in the absence of hosts for up to 10 days did not have reduced ability to parasitize, is not only an advantage for $\mathrm{ABC}$ in the field, but also for mass rearing in the laboratory. To meet needs for insect rearing or for $\mathrm{ABC}$ in the field, our results suggest that $T$. remus adults can be stored at $25^{\circ} \mathrm{C}$ for later use without any impairment of their subsequent parasitism performance.

Sex ratio is another important biological characteristic of parasitoids in biological control programs. Specifically, higher production of females is desirable since they are responsible for the direct suppression of the target pest (BUENO et al., 2009). As reported by Schwartz and Gerling (1974), the proportion of males in the progeny of T. remus increases with female age, especially after adults are 6 days old. Such inversion in the sex ratio of parasitoid offspring as the age female increases may be due to a decrease or lack of sperm in the spermatheca, which consequently decreases the number of fertilized eggs and thus the number of females in the next generation (HOUSEWEART et al., 1983). However, in the absence of host eggs, sperm remained viable for the 10 days evaluated in our experiment, and the sex ratio always remained higher than 0.60 , which is considered adequate for ABC programs (VAN LETEREN; BUENO, 2003). Notably, with regard to sex ratio, despite the statistical difference presented in the treatments with 1- and 2-day-old females compared to 9-day-old females, there was no difference between sex ratios in the progeny of wasps of other ages. Progeny of the 1- and 2-day-old females had similar sex ratios as the progeny of 3- to 8-day-old and 10-day-old females. Similarly, progeny of 9-day-old females had similar sex ratios as progeny 3 - to 8 - and 10-dayold females. Nevertheless, there was tendency for younger females ( 1 and 2 days old) in the experiment to have a lower sex ratio than older wasps, which might be explained by the type of reproduction in this insect. Reproduction of $T$. remus occurs by arrhenotokous parthenogenesis, (PRATISSOLI et al., 2014), in which unfertilized females produce haploid males, and fertilized females produce both females and males. Therefore, unfertilized females are restricted to producing male progeny (BOIVIN, 2010). The trend of greater numbers of males in the progeny of 1- and 2-day-old females may have been due to less time available for mating for these wasps, which had less contact with males because they transferred away from them after only 24 and 48 hours of age, respectively. However, it is difficult to explain why 10-day-old females did not also show an increase in proportion of males in their progeny. 
Host age is a limiting factor in the performance of egg parasitoids in the field and directly affects the choice of the parasitoid species used in ABC. In the present study, T. remus preferred to parasitize 24and 48-hour-old $S$. frugiperda eggs over 72-hourold eggs. Their preference for younger eggs may be related to internal and external characteristics of the eggs. When parasitoid females approach eggs of a pest, they examine and drum on the eggs with their antennae to discriminate whether the eggs are suitable for oviposition. As embryonic development advances, there is a reduction in egg nutrient content, making them lower quality for the parasitoid. Such changes in the internal characteristics of host eggs could result in a decrease in parasitism (NAVARAJAM, 1979; SCHMIDT; SMITH, 1987; STRAND; VINSON, 1986). This may explain the negative relationship between host egg age and parasitism potential of $T$. remus females. In addition, occurrence of parasitism in older eggs forces the larva of the parasitoid to develop more rapidly, which can generate deformed individuals unable to emerge (PIZZOL et al., 2012).

Lower parasitism by $T$. remus on 72-hour-old $S$. frugiperda eggs may also be related to hardening of the corium as embryonic development occurs, limiting the penetration capacity of the parasitoid ovipositor (PAK et al., 1986). Thus, parasitoids require more time to oviposit in older eggs, resulting in fewer parasitized (FARIA et al., 2000). This behavior might have relevance in the field, where there could be an overlap of different ages of the pest eggs, hence influencing the performance of the parasitoid, the results of the present study suggest that parasitoids would prefer to oviposit in and have higher performance in younger eggs. However, despite the lower parasitism of 72-hourold eggs, there was no influence of $S$. frugiperda egg age of on the parasitoid emergence (\%) and sex ratio of $T$. remus. Similar findings were reported by Borges Filho et al. (2017), who also did not observe an influence of Pachycoris torridus (Scopoli) (Hemiptera: Scutelleridae) egg age on the emergence and sex ratio of Telenomus pachycoris (Johnson) (Hymenoptera: Scelionidae).

To the best of our knowledge, the present study is the first report on the biological characteristics of $T$. remus and their potential importance for the successful use of this parasitoid in biological control programs. The absence of a reduction in parasitism among females from 1 to 10 days of age is a clear indication that in a host deprivation field situation, adults can maintain their parasitism and efficiency potential. This is unlike other species of egg parasitoids in which reabsorption of eggs occurs. In addition, this result suggests that it is possible to have a 10 day time delay between parasitoid adult production and use in the field without losses in biological control efficiency. This is a beneficial characteristic, as it means laboratory production capacity can be flexible with the demand for release of biological control agents in the field. We observed the influence of host egg age on the behavior of the T. remus females, as there was reduced acceptance of older hosts and consequently a reduction in parasitism. Such knowledge is crucial to maintaining the quality standard of $T$. remus in the laboratory, and also for optimizing field releases of parasitoids for the biological control of S. frugiperda.

\section{Acknowledgment}

The authors are grateful to Embrapa Soja, CAPES Foundation (Brazilian Ministry of Education), and the National Council of Scientific and Technological Development (CNPq, Brazilian Ministry of Science and Technology) for grants provided that supported this research.

\section{References}

BIEVER, K. D. Effect of the temperature on rate of search by Trichogramma and its potential application in field releases. Environmental Entomology, College Park, v. 1, n. 2, p. 194-197, 1972. Available at: https:// academic.oup.com/ee/article-abstract/1/2/194/2392468. Accessed at: 10 june 2018. DOI: 10.1093/ee/1.2.194 
BOIVIN, G. Reproduction and immature development of egg parasitoids. In: CÔNSOLI, F. L.; PARRA, J. R. P.; ZUCCHI, R. A. (Ed.). Egg parasitoids in agroecosystems with emphasis on Trichogramma. New York: Springer, 2010. cap. 1, p. 1-24.

BORGES FILHO, R. D. C.; NAVA, D. E.; PRATISSOLI, D.; POLANCZYK, R. A.; MARANGON, R. B.; LOIÁCONO, M. Biology of Telenomus pachycoris (Hymenoptera: Scelionidae), a parasitoid of eggs of Pachycoris torridus (Hemiptera: Scutelleridae): the effects of egg age, exposure time, and temperature. Florida Entomologist, Florida, v. 100, n. 2, p. 375379, 2017. Available at: http://www.bioone.org/ doi/ abs/10.1653/024.100.0238. Accessed at: 14 june 2018 . DOI: $10.1653 / 024.100 .0238$

BUENO, R. C. O. de F.; CARNEIRO, T. R.; PRATISSOLI, D.; BUENO A. F.; FERNANDES, O. A. Biology and thermal requirements of Telenomus remus reared on fall armyworm Spodoptera frugiperda eggs. Ciência Rural, Santa Maria, v. 38, n. 1, p. 1-6, 2008. Available at: http://www.scielo.br/scielo.php? pid $=$ S0103-84782008000100001\&script $=$ sci_arttext. Accessed at: 10 june 2018. DOI: $10.1590 / \mathrm{S} 0103-$ 84782008000100001 .

BUENO, R. C. O. de F.; PARRA, J. R. P.; BUENO, A. de F. Trichogramma pretiosum parasitism of Pseudoplusia includens and Anticarsia gemmatalis eggs at different temperatures. Biological Control, San Diego, v. 60, n. 2, p. 154-162, 2012. Available at: https://www.sciencedirect. com/science/article/pii/ S1049964411003173. Accessed at: 10 june 2018. DOI: 10.1016/j.biocontrol.2011.11.005

BUENO, R. C. O. F.; PARRA, J. R. P.; BUENO, A. F.; HADDAD, M. L. Desempenho de Tricogramatídeos como potenciais agentes de controle de Pseudoplusia includens Walker (Lepidoptera: Noctuidae). Neotropical Entomology, Londrina, v. 38, n. 3, p. 389-394, 2009. Disponível em: http://C:/Users/annap/ Downloads/ NE-85-733-57929-1-PB.pdf. Acesso em: 12 june 2018. DOI:10.1590/S1519-566X2009000300015

BURR, I. W.; FOSTER, L. A. A test for equality of variances. West Lafayette: University of Purdue, 1972. n. 282,26 p.

BUSATO, G. R.; GRÜTZMACHER, A. D.; OLIVEIRA, A. C. de; VIEIRA, E. A.; ZIMMER, P. D.; KOPP, M. M.; BANDEIRA, J. de M.; MAGALHÃES, T. R. Análise da estrutura e diversidade molecular de populações de Spodoptera frugiperda (J. E. Smith) (Lepidoptera: Noctuidae) associadas às culturas do milho e arroz no Rio Grande do Sul. Neotropical Entomology, Londrina, v. 33, n. 6, p. 709-716, 2004. Disponível em: $\quad$ http://www.scielo.br/scielo.php?script=sci rttext\&pid $=$ S1519566X2004000600008\&lng=pt\&nrm= iso\&tlng=pt. Acesso em: 15 june 2018. DOI: 10.1590/ S1519-566X2004000600008

CARNEIRO, T. R.; FERNANDES, O. A.; CRUZ, I. Influência da competição intra-específica entre fêmeas e da ausência de hospedeiro no parasitismo de Telenomus remus Nixon (Hymenoptera, Scelionidae) sobre ovos de Spodoptera frugiperda (JE Smith) (Lepidoptera, Noctuidae). Revista Brasileira de Entomologia, Curitiba, v. 53, n. 3, p. 482-486, 2009. Disponível em: http://www. scielo.br/scielo.php?script $=\quad$ sci_arttext\&pid $=$ S0085$56262009000300001 \& \operatorname{lng}=\mathrm{pt} \& \mathrm{nrm}=$ iso $\& \operatorname{tn} \mathrm{ln}=\mathrm{en}$. Acesso em: 20 june 2018. DOI: 10.1590/S008556262009000300001

CASMUZ, A.; JUÁREZ, M. L.; SOCÍAS, M. G.; MURÚA, M. G.; PRIETO, S.; MEDINA, S.; WILLINK, E.; GASTAMINZA, G. Revisión de los hospedeiros del gusano cogollero del maíz, Spodoptera frugiperda (Lepidoptera: Noctuidae). Revista de la Sociedad Entomológica Argentina, Buenos Aires, v. 69, n. 3-4, p. 209-231, 2010. Disponible en: $\quad$ http://www.scielo.org.ar/scielo.php?script=sci arttext\&pid=S0373-56802010000200007. Consultado el: 15 june 2018.

CAVE, R. D. Biology, ecology and use in pest management of Telenomus remus. Biocontrol News and Information, Wallingford, v. 21, n. 1, p. 21-26, 2000. Available at: http://cabweb.org/PDF/BNI/Control/ BNIRA52.pdf. Accessed at: 12 june 2018.

CHABI-OLAYE, A.; SCHULTHESS F.; POEHLING, H. M.; BORGEMEISTER, C. Factors affecting the biology of Telenomus isi (Polaszek) (Hymenoptera: Scelionidae), an egg parasitoid of cereal stem borers in West Africa. Biological Control, San Diego, v. 21, n. 1, p. 44-54, 2001. Available at: https://www. sciencedirect.com/ science/article/pii/S1049964401909223. Accessed at: 10 june 2018. DOI: 10.1006/bcon.2001.0922

CINGOLANI, M. F.; GRECO, N. M.; LILJESTHRÖM, G. G. Effect of Telenomus podisi, Trissolcus urichi, and Trissolcus basalis (Hymenoptera: Platygastridae) age on attack of Piezodorus guildinii (Hemiptera: Pentatomidae) eggs. Environmental entomology, Lanham, v. 43, n. 2, p. 377-383, 2014. Available at: https://academic.oup.com/ ee/article/43/2/377/529872. Accessed at: 12 june 2018. DOI: $10.1603 /$ EN13250

CRUZ, I. Manual de identificação de pragas do milho $e$ de seus principais agentes de controle biológico. Brasília: EMBRAPA Informação Tecnológica; Sete Lagoas: EMBRAPA Milho e Sorgo, 2008. 192 p. 
FARIA, C. A.; TORRES, J. B.; FARIAS, A. M. I. Resposta funcional de Trichogramma pretiosum Riley (Hymenoptera: Trichogrammatidae) parasitando ovos de Tutaabsoluta(Meyrick)(Lepidoptera:Gelechiidae): efeito da idade do hospedeiro. Anais da Sociedade Entomológica do Brasil, Londrina. v. 29, n. 1, p. 85-93, 2000. Disponível em: $\quad$ https://www.scielo.br/scielo.php?script=sci arttext\&pid=S0301-80592000000100011. Acesso em: 20 june 2018. DOI: 10.1590/S0301-80592000000100011.

FERNANDES, F. L.; BACCI, L.; FERNANDES, M. S. Impact and selectivity of insecticides to predators and parasitoids. EntomoBrasilis, Piracicaba, v. 3, n. 1, p. 1-10, 2010. Available at: https://periodico.ebras. bio.br/ ojs/index.php/ebras/article/view/52. Accessed at: 10 june 2018.

FLEURY, F.; BOULETREAU, M. Effects of temporary host deprivation on the reproductive potencial of Trichogramma brassicae. Entomologia Experimentalis et Applicata, Dordrecht, v. 68, n. 3, p. 203-210, 1993. Available at: https://onlinelibrary. wiley. com. Accessed at: 17 june 2018. DOI: $10.1111 /$ j.1570-7458.1993. tb01705.x

GARCIA, P.; WAJNBERG, E.; OLIVEIRA, L.; TAVARES, J. Is the parasitization capacity of Trichogramma cordubensis influenced by the age females? Entomologia Experimentallis et Applicata, Amsterdam, v. 98, n. 2, p. 219-224, 2001. Available at: https://onlinelibrary.wiley.com. Accessed at: 20 june 2018. DOI: 10.1046/j.1570-7458.2001.00777.x

GRANDE, M. L. M.; BRAZ, E. C.; BUENO, A. F.; SILVA, D. M.; QUEIROZ, A. P.; VENTURA, M. U. Effect of increasing rate of insecticides on its selectivity for Trichogramma pretiosum Riley (Hymenoptera: Trichogrammatidae). Semina: Ciências Agrárias, Londrina, v. 39, n. 3, p. 933-946, 2018. Available at: http://www.uel.br/revistas/uel/index. php/semagrarias. Accessed at: 17 june 2018. DOI: 10.5433/1679-0359.2018v39n3p933

GREENE, G. L.; LEPLA, N. C.; DICKERSON, W. A. Velvet bean caterpillar: a rearing procedure and artificial medium. Journal of Economic Entomology, Lanham, v. 69, n. 4, p. 488-497, 1976. Available at: https://academic. oup.com/jee/article/69/4/487/2212175. Accessed at: 11 june 2018. DOI: $10.1093 /$ jee/69.4.487

HOUGARDY, E.; BEZEMER, T. M.; MILLS, N. J. Effects of host deprivation and egg expenditure on the reproductive capacity of Mastrus ridibundus, an introduced parasitoid for the biological control of codling moth in California. Biological Control, San Diego, v. 33, n. 1, p. 96-106, 2005. Available at: https://www. sciencedirect.com/science/article/pii/
S1049964405000277. Accessed at: 17 june 2018. DOI: 10.1016/j.biocontrol.2005.01.013

HOUSEWEART, M. W.; JENNINGS, D. T.; WELTY, C.; SOUTHARD, S. G. Progeny production by Trichogramma minutum (Hymenoptera: Trichogrammatidae) utilizing eggs for Choristoneura fumiferana (Lepidoptera: Tortricidae) and Sitotroga cerealella (Lepidoptera: Gelechiidae). Canadian Entomologist, Ottawa, v. 115, n. 10, p. 1245-1252, 1983. Available at: https://www. cambridge.org/core/journals/ canadian-entomologist/ article. Accessed at: 20 june 2018. DOI: 10.4039/ Ent1151245-10

LOPES, J. R. S.; PARRA, J. R. P. Efeito da idade de ovos do hospedeiro natural e alternativo no desenvolvimento e parasitismo de duas espécies de Trichogramma. Revista de Agricultura, Piracicaba, v. 66, n. 3, p. 221244, 1991. Disponível em: http://www.nhm.ac.uk/ resources/research-curation/projects/ chalcidoids/pdf_X/ PastorMoBo2010. pdf. Acesso em: 20 jun. 2018.

MARTINELLI, S.; CLARK, P. L.; ZUCCHI, M. I.; SILVA-FILHO, M. C.; FOSTER, J. E.; OMOTO, C. Genetic structure and molecular variability of Spodoptera frugiperda (Lepidoptera: Noctuidae) collected in maize and cotton fields in Brazil. Bulletin of Entomological Research, Stanford, v. 97, n. 3, p. 225-231, 2007. Available at: https://doi.org/10.1017/ S0007485307004944. Accessed at: 12 june 2018. DOI: 10.1017/S0007485307004944

MENDES, S. M.; BOREGAS, K. G. B.; LOPES, M. E.; WAQUIL, M. S.; WAQUIL, J. M. Respostas da lagarta-do-cartucho a milho geneticamente modificado expressando a toxina Cry 1A(b). Pesquisa Agropecuária Brasileira, Brasília, v. 46, n. 3, p. 239- 244, 2011. Disponível em: http:/seer.sct.embrapa. br/index.php/ pab/article/view/9582/6258. Acesso em: 15 jun. 2018.

MILLS, N. J.; KUHLMANN, U. The relationship between egg load and fecundity among Trichogramma parasitoids. Ecological Entomology, London, v. 25, n. 3, p. 315-324, 2000. Available at: https:// onlinelibrary. wiley.com/doi/full/10.1046/j.1365-2311.2000.00260.x. Accessed at: 17 june 2018. DOI: 10.1046/j.13652311.2000.00260.x.

MOREAU, J.; RICHARD, A.; BENREY, B.; THIE'RY, $D$. The influence of plant cultivar of the grapevine moth Lobesia botrana on the life history traits of an egg parasitoid. Biological Control, San Diego, v. 50, n. 2, p. 117-122, 2009. Available at: https://www.sciencedirect. com/science/article/pii/S1049964409000887. Accessed at: 12 june 2018. DOI: 10.1016/j.biocontrol.2009.03.017

MORENO, F.; PEREZ-MORENO, I.; MARCO, V. Effect of Lobesia botrana (Lepidoptera: Tortricidae) egg age, 
density, and UV treatment on parasitism end development of $T$. cacoeciae (Hymenoptera: Trichogrammatidae). Environmental Entomology, Lanham, v. 38, n. 5, p. 15131520, 2009. Available at: https://academic.oup.com/ee/ article-abstract/38/5/1513/411153. Accessed at: 15 june 2018. DOI: $10.1603 / 022.038 .0520$

NAVARAJAN, A. V. Influence of host age on parasitism by Trichogramma australicum and T. japonicum (Himenoptera: Trichogrammatidae). Journal of Applied Entomology, Paris, v. 87, n. 3, p. 277-281, 1979. Available at: https://onlinelibrary.wiley.com/doi/ abs/10.1111/j.1439-0418.1978.tb02453.x. Accessed at: 15 june 2018. DOI: 10.1111/j.1439-0418.1978.tb02453.x

OLIVEIRA, H. N.; PRATISSOLI, D.; COLOMBI, C. A.; ESPINDULA, M. C. Características biológicas de Trichogramma exiguum Pinto \& Platner em ovos de Corcyra cephalonica Stainton. Magistra, Cruz das Almas, v. 15, n. 1, p. 103-105, 2003.

OLIVEIRA, H. N.; SIMONATO, J.; GLAESER, D. F.; PEREIRA, F. F. Parasitismo of Helicoverpa armigera pupae (Lepidoptera: Noctuidae) by tetrastichus howardi and Trichospilus diatraeae (Hymenoptera: Eulophidae) Semina: Ciências Agrárias, Londrina, v. 37, n. 1, p. 111115, 2016. Available at: http://www. uel.br/revistas/uel/ index.php/semagrarias. Accessed at: 15 june 2018. DOI: 10.5433/1679-0359.2016v37n1p111

OZDER, N.; KARA, G. Comparative biology and life tables of Trichogramma cacoeciae, T. brassicae and $T$. evanescens (Hymenoptera: Trichogrammatidae) with Ephestia kuehniella and Cadra cautella (Lepidoptera: Pyralidae) as hosts at three constant temperatures. Biocontrol Science and Technology, Oxford, v. 20, n. 3, p. 245-255, 2010. Available at: https://www.tandfonline. com/doi/abs/ 10.1080/ 09583150903497880. Accessed at: 15 june 2018. DOI: 10.1080/09583150903497880

PAK, G. A.; BUIS, H. C. E. M.; HECK, I. C. C.; HERMANS, M.L.G. Behaviouralvariations amongstrains of Trichogramma spp.: host-age selection. Entomologia Experimentalis et Applicata, Dordrecht, v. 40, n. 3, p. 247-258, abr. 1986. Available at: https://onlinelibrary. wiley.com/doi/abs/10.1111/j.1570-7458.1986.tb00508.x. Accessed at: 15 june 2018. DOI: 10.1111/j.15707458.1986.tb00508.x

PIZZOL, J.; DESNEUX, N.; WAJNBERG, E.; THIÉRY, D. Parasitoid and host egg ages have independent e impacton various biological traits in a Trichogramma species. Journal of Pest Science, Sussex, v. 85, n. 1, p. 489-496, 2012. Available at: https://link.springer.com/ article/10.1007/s10340-012-0434-1. Accessed at: 12 june 2018. DOI: 10.1007/s10340-012-0434-1
PIZZOL，J.; PINTUREAU, B.; KHOUALDIA, O.; DESNEUX, N. Temperature dependente differences in biological traits between two strains of Trichogramma cacoeciae (Hym., Trichogrammatidae). Journal of Pest Science, Sussex, v. 83, n. 4, p. 447-452, 2010. Available at: https://link.springer.com/article/10.1007/ s10340010-0327-0. Accessed at: 17 june 2018. DOI: 10.1007/ s10340-010-0327-0

POGUE, M. G. A world revision of the genus Spodoptera Guenée (Lepidoptera: Noctuidae). Memoirs of the American Entomological Society, Gainesville, v. 43, n. 1, p. 117-124, 2002.

POLANCZYK, R. A.; PRATISSOLI, D.; HOLTZ, A. M.; PEREIRA, C. L. T.; FURTADO, A. S. Efeito da idade de Trichogrammaexiguumedodesenvolvimentoembrionário da traça-das-crucíferas sobre as características biológicas do parasitoide. Biological Sciences, Maringá, v. 29, n. 2, p. 161-166, 2007. Disponível em: http://www.redalyc. org/html/1871/187115764007/. Acesso em: 12 jun. 2018.

POMARI, A. F.; BUENO, A. F.; BUENO, R. C. O. D. F.; MENEZES, A. O. Telenomus remus Nixon egg parasitization of three species of Spodoptera under different temperatures. Neotropical Entomology, Londrina, v. 42, n. 4, p. 399-406, 2013. Available at: https://link.springer.com/article/10.1007/s13744-0130138-0. Accessed at: 20 june 2018. DOI: 10.1007/ s13744-013-0138-0

PRATISSOLI, D.; KLOSS, T. G.; ZINGER, F. D.; CARVALHO, J. R.; VIANNA, U. R.; PAES, J. P. Does mating interfere in the biological characteristics of a population of Trichogramma pretiosum? Anais da Academia Brasileira de Ciências, Rio de Janeiro, v. 86, n. 1, p. 459-464, 2014. Available at: $\quad \mathrm{http} / / / \mathrm{www} . \quad$ scielo.br/scielo.php?pid=S000137652014000100459\&script=sci_arttext\&tlng=es. Accessed at: 12 june 2018. DOI: 10.1590/00013765201496712

QUEIROZ,A.P.;BUENO,A.F.;POMARI-FERNANDES A.; GRANDE, M. L. M.; BORTOLOTTO, O. C.; SILVA, D. M. Quality control of Telenomus remus (Hymenoptera: Platygastridae) reared on the factitious host Corcyra cephalonica (Lepidoptera: Pyralidae) for successive generations. Bulletin of Entomological Research, Stanford, v. 107, n. 6, p. 791-798, 2017a. Available at: https://www.cambridge.org/core/journals/bulletinof-entomological-research/article/quality-controlof-telenomus-remus-hymenoptera-platygastridaereared-on-the-factitious-host-corcyra-cephalonicalepidoptera-pyralidae-for-successive-generations/ ADC9D4673C986E61C7E99820BFE90AAC. Accessed at: 17 june 2018. DOI: 10.1017/S000748531700030X 
QUEIROZ, A. P.; TAGUTI, E. A.; BUENO, A. F.; GRANDE, M. L. M.; COSTA, C. O. Host Preferences of Telenomus podisi (Hymenoptera: Scelionidae): Parasitism on Eggs of Dichelops melacanthus, Euschistus heros, and Podisus nigrispinus (Hemiptera: Pentatomidae). Neotropical Entomology, Londrina, v. 47, n. 4, p. 543-552, 2017b. Available at: https://link.springer. com/article/10.1007/s13744-017-0564-5. Accessed at: 15 june 2018. DOI: 10.1007/s13744-017-0564-5

ROCHA, L.; KOLBERG, R.; MENDONÇA, J. R. M. S.; REDAELLI, L. R. Effects of egg age of Spartocera dentiventris (Berg) (Hemiptera: Coreidae) on parasitism by Gryongallardoi(Brethes)(Hymenoptera: Scelionidae). Neotropical Entomology, Londrina, v. 35, n. 5, p. 654659, 2006. Available at: http://www. scielo.br/scielo. php? pid $=$ S 1519-566X2006000500013\&script $=$ sci arttext\&tlng=pt. Available at: 18 june 2018. DOI: 10.1590/S1519-566X2006000500013

SCHMIDT, J. M.; SMITH, J. J. B. The measurement of exposed host volume by the parasitoid wasp Trichogramma minutum and effects of wasp size. Canadian Journal of Zoology, Ottawa, v. 65, n. 12, p. 2837-2845, 1987. Available at: http://www.nrcresearchpress.com/doi/ abs/10.1139/z87-432. Accessed at: 18 june 2018. DOI: $10.1139 / \mathrm{z} 87-432$

SCHWARTZ, A.; GERLING, D. Adult biology of Telenomus remus (Hymenoptera: Scelionidae) under laboratory conditions. Entomophaga, Paris, v. 19, p. 482492, 1974. DOI: 10.1007/BF02372784

SHAPIRO, S. S.; WILK, M. B. An analysis of variance test for normality (complete samples). Biometrika, London, v. 52, n. 4, p. 591-611, 1965. DOI: 10.2307/2333709

SILVA, D. M.; BUENO, A. F.; ANDRADE, K.; STECCA, C. S.; NEVES, P. M. O. J.; MOSCARDI, F. Selectivity of organic compounds to the egg parasitoid Telenomus remus Nixon (Hymenoptera: Plastygastridae) Semina: Ciências Agrárias, Londrina, v. 37, n. 1, p. $55-$ 66, 2016. Available at: http://www.uel.br/revistas/uel/ index.php/semagrarias. Accessed at: 15 june 2018. DOI: 10.5433/1679-0359.2016v37n1p55

STATISTICAL ANALYSIS SYSTEM INSTITUTE SAS Institute. SAS/STAT ${ }^{\circledR} 9.2$ user's guide, ed. Cary: NC: SAS, 2009
STRAND, M. R.; VINSON, S. B. Analysis of an egg recognition kairomone of Telenomus heliothisdis (Hymenoptera: Scelionidae). Isolation and host function. Journal of Chemical Education, Tucson, v. 9, n. 3, p. 423-432, 1983. Available at: https://link.springer.com/ article/10.1007/BF00988459. Accessed at: 17 june 2018. DOI: $10.1007 / \mathrm{BF} 00988459$

THULER, R. T.; VOLPE, H. X. L.; BORTOLI, S. A.; GOULART, R. M.; VIANA, C. L. T. Metodologia para avaliação da preferência hospedeira de parasitoides do gênero Trichogramma Westood. Boletín de Sanidad Vegetal, Plaga, v. 33, n. 3, p. 333-340, 2007. Available at: https://dialnet.unirioja.es/servlet/ articulo codigo $=2513618 \&$ orden $=0 \&$ info $=$ link . Accessed at: 15 jun. 2018.

VAN LENTEREN, J. C.; BOLCKMANS, K.; KÖHL, J.; RAVENSBERG, W. J.; URBANEJA, A. Biological control using invertebrates and microorganisms: plenty of new opportunities. BioControl, Dordrech, v. 63, n. 1, p. 39-59, 2017. Available at: https://link.springer.com/ article/10.1007/s10526-017-9801-4. Accessed at: 15 june 2018. DOI: 10.1007/s10526-017-9801-4

VAN LENTEREN, J. C.; BUENO, V. H. P. Augmentative biological control of arthropods in Latin America. Biocontrol, Dordrech, v. 48, n. 2, p. 123-139, 2003. Available at: https://link.springer.com/article/10.1023/ A:1022645210394. Accessed at: 16 june 2018. DOI: 10.1023/A:1022645210394

VENTURA, G. P. E.; WEINBERG, M. L.; MENLO, O.; AVIARIES, J. Is the parasitization capacityy of Trichogramma crudeness influenced by the age of the females? Entomologia Experientalis et Applicata, Dordrecht, v. 98, n. 2, p. 219-224, 2001. Available at: https://onlinelibrary.wiley.com/doi/abs/ 10.1046 /j.15707458.2001.00777.x. Accessed at: 18 june 2018. DOI: 10.1046/j.1570-7458.2001.00777.x

ZUIM, V.; RODRIGUES, H. S.; PRATISSOLI, D.; TORRES, J. B.; FRAGOO, D. F. M.; BUENO, R. C. O. F. Age and density of eggs of Helicoverpa armigera influence on Trichogramma pretiosum parasitism. Acta Scientiarum. Maringá, v. 39, n. 4, p. 513-520, 2017. Available at: http://www.redalyc. org/pdf/1871/ 187153564015.pdf. Accessed at: 15 june 2018. DOI: 10.4025/actascibiolsci.v39i4.34943 
